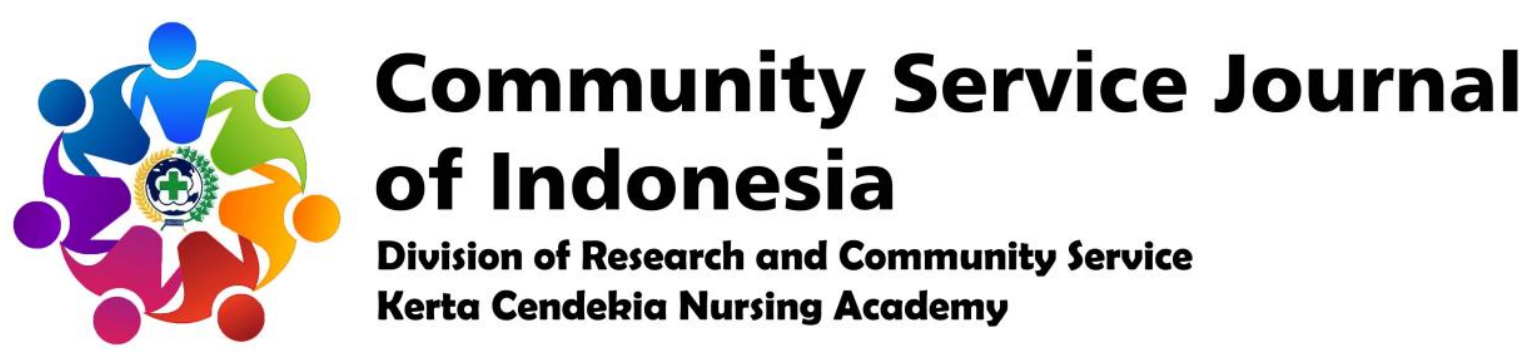

https://ejournal-kertacendekia.id/index.php/csji/index

\author{
Community Service Journal of Indonesia 3 (2) (2021): 41-46 \\ Doi: https://doi.org/10.36720/csji.v3i2.334
}

\title{
ASIVA (AKU SIAP VAKSIN) AS AN EFFORT TO IMPROVE COMMUNITY KNOWLEDGE AND READINESS TO RECEIVE THE COVID-19 VACCINATION
}

\author{
Yurike Septianingrum ${ }^{1 *}$, Lono Wijayanti ${ }^{1}$, Sulistyorini ${ }^{1}$
}

\author{
${ }^{1}$ Nursing Department, Faculty of Nursing and Midwifery, Universitas Nahdlatul Ulama \\ Surabaya \\ * Correspondence \\ Yurike Septianingrum \\ Nursing Department, Faculty of Nursing and Midwifery, Universitas Nahdlatul Ulama Surabaya \\ SMEA Road Number 57, Surabaya City, East Java Province, Indonesia \\ Email: yurikesepti1209@unusa.ac.id
}

\begin{abstract}
Information that is not true or commonly called a "hoax" about the Covid-19 vaccine circulating in the community makes people restless and confused, and if this is not addressed immediately, more and more people refuse to be vaccinated. Health cadres have a role in educating the public about Covid-19 vaccination, but in reality their activities have been inactive during the pandemic. The ability to conduct health education by utilizing technology is still lacking, so it is necessary to provide training on how to conduct health education to cadres. The purpose of this activity is to increase the knowledge and readiness of health cadres in an effort to increase knowledge and readiness of the community to receive the Covid-19 vaccinnation through the ASIVa (Aku Siap Vaksin) program. The method used in this community service activity is a participative educational approach, namely providing health education to cadres about the Covid-19 vaccine and training on how to use technology for health promotion. This activity was carried out for one month and was attended by ten health cadres. The results of community service show that the knowledge of the cadres is very good, skilled and interactive in carrying out health education.
\end{abstract}

Keywords: Health Education, Covid-19 Vaccination, Health Cadres, Health Cadre Training.

(C) 2021 The Authors. Community Service Journal of Indonesia Published by Institute for Research and Community Service Health Polytechnic of Kerta Cendekia, Sidoarjo

This is an Open Access Article distributed under the terms of the Creative Commons Attribution-NonCommercial 4.0 (CC BY-NC 4.0), which allows others to remix, tweak, and build upon the work non-commercially as long as the original work is properly cited. The new creations are not necessarily licensed under the identical terms.

\author{
E-ISSN \\ 2684-7884 \\ P-ISSN \\ 2774-4027
}




\section{INTRODUCTION}

The Covid-19 pandemic that has spread worldwide has infected more than 5 million people in 215 countries or regions and caused more than 300,000 deaths worldwide (Lin et al., 2020). Although the WHO program of wearing masks and keeping a distance is quite effective in preventing the transmission of Covid-19, long-term control of Covid-19 depends on the development, distribution and use of the Sars-CoV-2 vaccine (Chou \& Budenz, 2020). The challenges faced when distributing vaccines are the rejection of vaccines by the community for reasons of safety, effectiveness, and different perspectives from the community (Dror et al., 2020).

According to a survey conducted by the Indonesian Ministry of Health regarding vaccine receipts which took place from 19 to 30 September 2020 on 115,000 respondents from 34 provinces, it showed that around $65 \%$ of respondents stated that they were willing to accept the COVID-19 vaccine if provided by the government, while eight percent of them refused. The remaining $27 \%$ expressed doubts about the Government's plan to distribute the COVID-19 vaccine. This situation needs to be understood carefully; the public may have different levels of confidence in the COVID19 vaccine due to limited information about the type of vaccine, when the vaccine will be available and its safety profile. Respondents expressed concerns about the safety and effectiveness of vaccines, expressed distrust of vaccines, and questioned the "halalness" of vaccines. The most common reasons for rejection of the COVID-19 vaccine were related to vaccine safety $(30 \%)$; doubts about the effectiveness of the vaccine (22\%); distrust of vaccines $(13 \%)$; concern about side effects such as fever and pain (12\%); and religious reasons (8\%) (Kementerian Kesehatan Republik Indonesia et al., 2020).

\section{Overview of The Target Community}

The Manyar Sambongan area is located

in Kertajaya Village, Gubeng District,
Surabaya. There are 3 RW (Rukun Warga) in Kertajaya Village, one of which is RW 03 in Manyar Sambongan. The Manyar Sambongan area is located near the Manyar market, and there are 2 schools namely, Maryam Kindergarten-SD-SMP-SMA and Galuh Handayani Inclusion School. This area is quite densely populated and most of them are middle- and lower-middle-income people. From the results of interviews with 10 residents in RW 03, it is known that 5 people are willing to receive the vaccine, 3 people are still hesitant to receive the vaccine, and 2 people refuse the vaccine. Those who want to receive the vaccine do not know how the vaccine works because they only follow the government's recommendation to follow the vaccination and are afraid of being fined if they refuse, while residents who are still hesitant say they are still afraid of the side effects and safety of the vaccine, while those who refuse the vaccine state that they are in a condition healthy without being vaccinated. And vaccines actually harm their bodies. The amount of information that is not true or commonly called a "hoax" about the Covid-19 vaccine circulating in the community makes people restless and confused, especially since this kind of information circulates quickly considering the conditions in the area near the crowded market. If this is not addressed and misinformation is not immediately rectified, it is feared that more and more people will refuse the vaccine. The government cannot force the public to accept the vaccine with the threat of a fine because this can violate human rights, so there must be awareness from the community itself to voluntarily and without coercion receive the Covid-19 vaccine. The Covid-19 vaccine given is expected to be able to reduce the number of cases of Covid-19 in RW 03 Manyar Sambongan Surabaya. So far, health promotion regarding the Covid-19 vaccine has never been given in the RW 03 Manyar Sambongan area.

The first level health facility for residents of RW 03 Manyar Sambongan is the Pucang Sewu Health Center. Currently, the Puskesmas 
has formed health cadres in the community, such as posyandu cadres for toddlers, the elderly, and bumantik. The role of health cadres is very large in the community in providing health promotion. They are active in health promotion activities. Regular meetings are held once a month, and the schedule for each cadre is different. During this pandemic, the activities of these health cadres must temporarily stop. On the other hand, most of the cadres are elderly, and do not master technology, so the activities of health cadres really do not work (vacuum).

\section{OBJECTIVES}

General Purpose

After the implementation of the ASiVa program, it is hoped that the health cadres will be able to know and give health education to their community.

\section{Special Purpose}

1. Provide health education to existing health cadres online and offline so that they are also able to educate the public about the Covid-19 vaccine

2. Health promotion provided online through videos uploaded on WAG and YouTube, as well as providing a module on ASIVa to cadres as a guide in conducting health education.

3. Teaching health cadres to use gadgets, especially applications to promote health such as zoom, YouTube, and WhatsApp.

\section{PLAN OF ACTION}

\section{Strategy Plan}

The method used in this community service activity is a participative educational approach that will be held on 5-12 June 2021 at the house of one of the cadres and attended by 10 health cadres in RW 03 Manyar Sambongan, Kertajaya Village, Gubeng District.

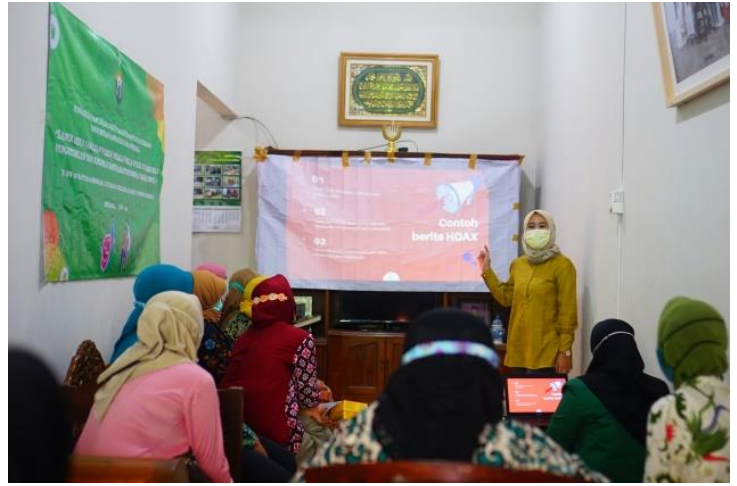

\section{Implementation}

The training for health cadres in the first week was in the form of introducing technology for health promotion to cadres such as the Zoom, Google Meet, YouTube, and WhatsApp applications. Cadres are taught how to make educational videos using mobile phones and zoom then upload educational videos on Youtube. This training also teaches cadres how to provide good health promotion to residents by providing ASIVa e-modules. The Knowledge Observation Sheet on Covid19 Vaccination will measure the knowledge of the cadres via Google form before and after being given health education. The evaluation of the activities was carried out in the second week after the cadres uploaded health education videos on the WhatsApp group. The assessment is carried out by looking at the way the cadres provide health promotion about the Covid-19 vaccine uploaded on YouTube and WAG with the assessment criteria seen from appearance, communication, and mastery of the material.

\section{Setting}

This community service was held on September 5-12 June 2021 at the house of one of the cadres, RW 03 Manyar Sambongan, Kertajaya Village, Gubeng District, Surabaya. 
Target

Participants are health cadres in RW 03 Manyar Sambongan, Kertajaya Village, Gubeng District as many as 10 health cadres.

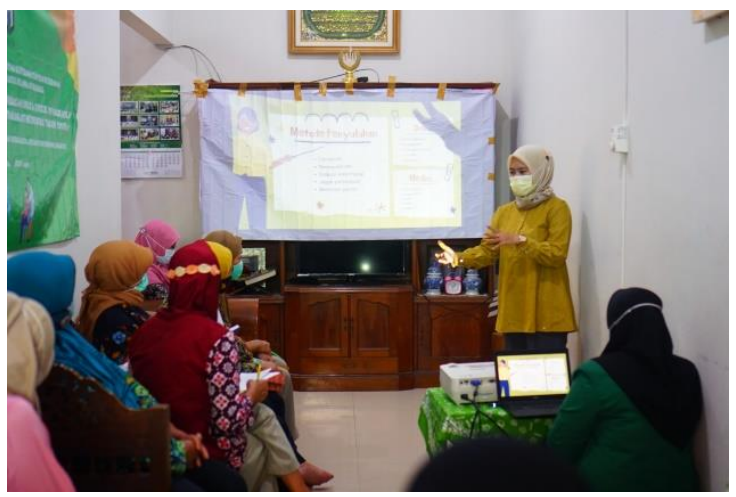

\section{RESULTS AND DISCUSSION}

The results of the knowledge of health cadres about Covid-19 vaccination before and after training are as follows:

Table 1. Results of pre-test and post-test

\begin{tabular}{|c|c|c|c|c|}
\hline Score & Mean & SD & Min-Max. & $P$ \\
\hline Pre-test & 43 & 9.5 & -56.52 to $-47,48$ & 0.000 \\
\hline Post-test & 95 & 7.1 & & \\
\hline
\end{tabular}

Based on table 1, the results of the pre-test and post-test of cadres' knowledge about covid-19 vaccination showed that there was a significant difference ( $p=$ 0.000) which meant that there was an increase in knowledge about covid-19 vaccination after being given training. This increase in knowledge becomes a benchmark that cadres are ready to provide health education to the residents of Manyar Sambongan.

Health education about vaccines focuses on the effectiveness of covid-19 vaccination, safety, halal status, and side effects of vaccination. Vaccines provide immediate protection by reducing susceptibility to disease or infection. The effects of these vaccines can be assessed in clinical trials by measuring their efficacy for preventing disease, preventing infection, and reducing transmission (Lipsitch \& Dean, 2020). Several Covid19 vaccines are developed to a late stage and are ready to be distributed evenly to all affected areas, especially low-resource areas as a global COVID-19 vaccine development effort guided by three imperatives: speed, manufacture and largescale deployment, and global access (Le et al., 2020).

There are four vaccines that have been distributed throughout the world, including Indonesia, namely Sinovac, AstraZeneca, Moderna, Pfizer. Moderna and Pfizer vaccines showed $94.1 \%$ and 95\% effectiveness, while Sinovac and AstraZeneca showed $78 \%$ and $70.4 \%$ effectiveness, respectively. Although the COVID-19 vaccine is quite effective in preventing transmission, the public still has to comply with the health protocol (Halim et al., 2021).

At the next meeting, the cadres were asked to demonstrate health education after receiving training the previous week. Cadres have an important role in increasing public knowledge about vaccination. Counseling and training for health cadres in preventing the transmission of covid-19 has been carried out, as well as demonstrations for making hand sanitizer (Hernawan Diana; Meylani, Vita; Agustian, Dita, 2021). Community service focuses on empowering communities to be effective in improving health status. Community empowerment is the efforts made to increase capacity and involve the community in achieving communication goals. Through community empowerment, the community is not positioned as a passive actor but 
plays an active role in handling and assisting the resolution of impacts related to COVID-19 and or vaccines. Community empowerment also serves to maximize the effectiveness of the adoption of key messages through collective responses and ultimately prevent transmission at the community level. By increasing community participation through their involvement in the COVID-19 vaccination program, the health sector has the opportunity to provide vaccination services in a realistic, relevant and appropriate manner to the needs and challenges of the target group. Therefore, community empowerment - in line with the results of situational analysis research is the front line in the COVID-19 vaccination program that needs to get great attention from various parties. (Kemenkes RI, 2020).

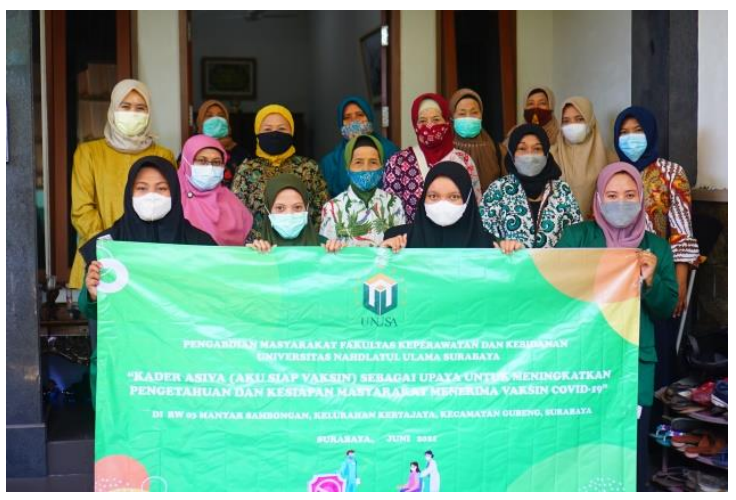

\section{CONCLUSION}

Community empowerment through health cadres in the AsiVa program is quite effective in increasing the knowledge of health cadres about Covid-19 vaccination. Training on how to conduct counseling improves the ability of cadres to conduct health education. The results of this community service are expected to be applied by cadres in a sustainable manner. Community empowerment through the use of technology is very important, therefore the Surabaya city government is expected to conduct training like this for all cadres in the city of Surabaya, so that activities for health cadres are not vacuumed during the covid-19 pandemic.

\section{REFERENCES}

Chou, W. Y. S., \& Budenz, A. (2020). Considering Emotion in COVID-19 Vaccine Communication: Addressing Vaccine Hesitancy and Fostering Vaccine Confidence. Health Communication, 35(14), 1718-1722. https://doi.org/10.1080/10410236.202 0.1838096

Dror, A. A., Eisenbach, N., Taiber, S., Morozov, N. G., Mizrachi, M., Zigron, A., Srouji, S., \& Sela, E. (2020). Vaccine hesitancy: the next challenge in the fight against COVID19. European Journal of Epidemiology, 35(8), 775-779. https://doi.org/10.1007/s10654-02000671-y

Halim, M., Halim, A., \& Tjhin, Y. (2021). COVID-19 Vaccination Efficacy and Safety Literature Review. Journal of Clinical and Medical Research, 3(1), $1-10$.

Hernawan Diana; Meylani, Vita; Agustian, Dita, E. H. (2021). Penyuluhan Dan Pelatihan Kader Desa Dalam Pencegahan Penularan Covid19. Abdimas Dewantara, 4(Vol 4, No 1 (2021)), 100-109. https://jurnal.ustjogja.ac.id/index.php/ abdimasdewantara/article/view/8814/ 3912

Kemenkes RI, D. P. (2020). Keputusan Direktur Jenderal Pencegahan dan Pengendalian Penyakit Nomor Hk.02.02/4/1/2021 tentang Petunjuk Teknis Pelaksanaan Vaksinasi dalam Rangka Penanggulangan Pandemi 
Corona Virus Disease 2019 (COVID19). Kementerian Kesehatan RI, 4247608(021), 114. https://www.kemkes.go.id/article/vie w/19093000001/penyakit-jantungpenyebab-kematian-terbanyak-ke-2di-indonesia.html

Kementerian Kesehatan Republik Indonesia, ITAGI, WHO, \& UNICEF. (2020). Survei Penerimaan Vaksin COVID-19 di Indonesia. Satuan Gugus Tugas Penanganan COVID19, November.

Le, T. T., Andreadakis, Z., Kumar, A., Román, R. G., Tollefsen, S., Saville, M., \& Mayhew, S. (2020). The COVID-19 vaccine development landscape. Nature Reviews Drug Discovery, 19(May), 305-306. https://doi.org/10.1038/d41573-02000073-5

Lin, Y., Hu, Z., Alias, H., \& Wong, L. P. (2020). Knowledge , Attitudes, Impact , and Anxiety Regarding COVID-19 Infection Among the Public in China. 8(May), 1-7. https://doi.org/10.3389/fpubh.2020.00 236

Lipsitch, B. M., \& Dean, N. E. (2020). Understanding Covid-19 vaccine efficacy. 370(6518), 763-766. 